\title{
COVID-19 Pandemic Recession and Recovery
}

\author{
K. S. Jomo ${ }^{1} \cdot$ Anis Chowdhury ${ }^{2}$ \\ Published online: 16 November 2020 \\ (c) Society for International Development 2020
}

\begin{abstract}
This review draws pragmatic lessons for developing countries to address COVID-19-induced recessions and to sustain a developmental recovery. These recessions are unique, caused initially by supply disruptions, largely due to governmentimposed 'stay-in-shelter lockdowns'. These have interacted with falling incomes and demand, declining exports (and imports), collapsing commodity prices, shrinking travel and tourism, decreasing remittances and foreign exchange shortages. Highlighting implications for employment, wellbeing and development, it argues that governments need to design comprehensive relief measures and recovery policies to address short-term problems. These should prevent cash-flow predicaments from becoming full-blown solvency crises. Instead of returning to the status quo ante, developing countries' capacities and capabilities need to be enhanced to address long-term sustainable development challenges. Multilateral financial institutions should intermediate with financial sources at low cost to supplement the International Monetary Fund's Special Drawing Rights to lower borrowing costs for relief and recovery.
\end{abstract}

Keywords Debt · Deficit · Food security · Industry policy · Recession · Recovery · Relief · Sustainable development · Stimulus packages

The COVID-19 pandemic has significantly impacted most economies in the world. Its full impacts will not be felt, let alone measured, until it runs its course. Secondary effects will be around for much longer, with their consequences altering courses. Their implications are likely to extend beyond the medium-term, sometimes described as "permanent scars' or injuries, forever reducing capacities and capabilities, even if not reversibly. Most countries are still struggling to contain contagion, as the waves seem unending, while the costs on both lives and livelihoods will have long-term repercussions.

This article is based on the authors' opinion pieces published by the Inter Press Service (IPS) News Agency, which can be accessed at https://www.ipsnews.net/author/jomo-kwame-sundaram/ and https://www.ipsnews.net/author/anis-chowdhury/.

Anis Chowdhury

anis.z.chowdhury@gmail.com

K. S. Jomo

jomoks@yahoo.com

1 Khazanah Research Institute, Kuala Lumpur, Malaysia

2 School of Social Sciences and Psychology, Western Sydney University, Sydney, Australia
The global economic situation remains even more unpredictable than usual, with uncertainties about the varied nature of the pandemic recessions. Government responses have not only been diverse, but often poorly conceived due to the novel nature of the crises. Impacts have varied with the contagion and policy responses, ${ }^{1}$ unhelped by often confusing, if not misleading metrics. ${ }^{2}$

Such uncertainty is also reflected in the wide-ranging growth forecasts by major international organizations (e.g., OECD). ${ }^{3}$ The International Monetary Fund (IMF 2020a) has recognized the 'Great Lockdown' as due to 'self-imposed' contractions, leading to the 'worst recession since the Great Depression'. Most low-income developing countries (LIDCs) are in a particularly difficult position to respond. In an IMF blog, Gurara et al. (2020) noted, 'growth in LIDCs is likely to come to a standstill this year, compared to growth of 5\% in 2019. Further, absent a sustained international effort to support them, permanent scars are likely to harm

\footnotetext{
$1 \mathrm{http} / / / \mathrm{www}$.oecd.org/coronavirus/policy-responses/evaluating-theinitial-impact-of-covid-19-containment-measures-on-economic-activ ity-b1f6b68b/ Accessed 17 October 202.

2 https://www.washingtonpost.com/business/2020/06/05/may-2020jobs-report-misclassification-error/.

${ }^{3}$ http://www.oecd.org/economic-outlook/\#resources Accessed 17 October 2020.
} 
development prospects, exacerbate inequality, and threaten to wipe out a decade of progress reducing poverty'.

This review seeks to draw pragmatic lessons for developing countries to address the COVID-19-induced recession and recovery. It is divided into two broad sections. The first section is devoted to understanding the nature of the COVID-19 recession and various policy options for recovery. The second section argues that in addition to urgent relief measures, governments need to design comprehensive recovery policies to address short-term problems, such as preventing liquidity problems from becoming full-blown solvency crises, ${ }^{4}$ as well as long-term challenges associated with the Sustainable Development Goals (SDGs). In such circumstances, governments cannot be fettered by corporate and market preoccupations. Instead, multilateral development banks (MDBs) should urgently enable developing countries' capacities to develop better than ever. Meanwhile, the IMF's emergency lending power should be enhanced with Special Drawing Rights (SDRs) to prevent recessions from becoming protracted depressions (Gallagher et al. 2020; Herman 2020).

\section{COVID-19 Recessions: Different, Disruptive and Transformative}

The COVID-19 crisis has clearly been caused by both the pandemic and contagion containment policy responses, a public health threat unconnected to business conditions, operations and decisions. However, COVID-19 recessions have been quite varied due to different circumstances and responses. Various aspects may bear some resemblance to earlier 'supply-side' recessions, e.g., those caused or worsened by post-war conversion of armaments industries, oil price shocks (e.g., in 1973, 1979, 2007) and 'shock therapy'induced 'transformational recessions' in 'post-communist' and other economies in the 1990s.

Preventive and other precautionary measures to contain the epidemic, especially those associated with physical distancing, have disrupted production, supply and incomes, thus also reducing demand and spending differently in many sectors. Different types of economies, workplaces, workers, labour processes, social spaces, public transportation and so on have varied implications for spatial or physical distancing, proximate exposure and likelihood of infection.

\footnotetext{
${ }^{4}$ https://blogs.imf.org/2020/04/22/the-short-term-liquidity-line-anew-imf-tool-to-help-in-the-crisis/ Accessed 19 October 2020.
}

\section{COVID-19 Recessions Different}

There is not one single standard COVID-19 recession in different parts of the world, but rather a variety of contractionary experiences, often varying with the reasons, timing and circumstances of the slowdowns. Some may be quite unrelated to COVID-19, with others influenced by pre-existing conditions and trends combining with the epidemic's effects as well as both official and behavioural responses. At the risk of overstating the obvious, crises and recessions are always different, although some similarities may be more pronounced than others.

Unlike most recent contractions in the world, COVID19 recessions are not primarily financially driven; but preexisting financial fragility and vulnerabilities have worsened them. Therefore, better understanding of the varying role of liquidity and the nature of liquidity constraints in the economies of developing countries is crucial for designing and implementing more effective measures to provide cash support. Relief and recovery support measures must consider the variety of enterprises seeking to resume viable operations in the aftermath of involuntarily enforced suspension of activities during 'stay-in-shelter' lockdowns.

Recessions in many countries since the first half of 2020 are largely due to 'supply side' constraints imposed by state authorities during and after 'stay-in-shelter' lockdowns, as well as physical distancing and other precautionary preventive measures. These measures not only restricted 'normal' business operations, but also disrupted livelihoods. Reduced and uncertain incomes and diminished access to liquidity have reduced consumption and investment spending, and thus aggregate demand. Businesses relating to many social activities which involve close inter-personal physical proximity_including public transportation, religious gatherings and other public events-are especially vulnerable, and will require behavioural changes, as long as the virus threat remains.

With supply chains disrupted, the manufacturing sector has been especially hard hit. While border closures have devastating impacts on travel, tourism and international education, steep falls in commodity prices mean serious losses in export revenues, but also import liabilities. COVID-19 has posed the cruel public policy dilemma of having to contain the contagion while enabling livelihoods to continue.

Economic hardship has been compounded by international remittances declining by at least $20 \%$, i.e., by more than US\$100 billion. ${ }^{5}$ Remittances have generally worked in a counter-cyclical manner historically, and has been

\footnotetext{
5 https://www.worldbank.org/en/news/press-release/2020/04/22/ world-bank-predicts-sharpest-decline-of-remittances-in-recent-histo ry. Accessed 27 July 2020.
} 
more than three times more than official development assistance since the mid-1990s; in 2019, remittances may have exceeded foreign direct investment (FDI) flows to low- and middle-income countries. ${ }^{6}$ By mid-2020, 120 developing countries had approached the IMF for access to its emergency funding facilities for financial assistance. ${ }^{7}$

\section{COVID-19 Recessions Transformative}

A 'demand-side' recession typically involves declines in many, if not most industries, sectors and regions. Such output contraction implies underutilized production capacities, raising unemployment, albeit unevenly. A 'structural' recession usually refers to falling output in one or a few related industries, sectors or regions, not sufficiently offset by other rises.

A structural transformation-with 'unviable' activities declining as more 'competitive' alternatives grow-may not involve overall economic contraction if resource transfers-from declining activities to those emerging-are easy, rapid and low cost. Such resource transfers typically require 'repurposing' labour as well as plant, equipment and other 'fixed capital' stock. Unplanned or unmanaged structural transformations result in 'supply-side' recessions as resources are withdrawn without being redeployed for alternative productive ends.

Not all 'supply-side' recessions necessarily involve structural transformation, especially if not deliberately encouraged or 'nudged' by government. Left to markets and corporations alone, such adjustments typically increase unemployment as industries become unprofitable-e.g., due to cost spikes-and lay off workers. Growing unemployment lowers wages; although conventional wisdom insists that cheaper labour costs will induce new investments, it ignores the uncertainty that arises from such developments. Hence, consumption spending falls, which, in turn, dampens business spending. Market resolution of such unexpected, massive disruptions is unlikely to be well coordinated, quick and painless, with high unemployment typically persisting for years thereafter. Alternatively, governments can guide, facilitate and accelerate desired changes with appropriate relief and industrial policy measures.

Slumps in travel, tourism, mass entertainment, public events, hospitality services, educational services, personal services and other such activities have been due to containment requirements and related precautionary behaviour.

\footnotetext{
$\overline{6}$ https://blogs.worldbank.org/peoplemove/data-release-remittance s-low-and-middle-income-countries-track-reach-551-billion-2019. Accessed 27 July 2020.

7 https://www.imf.org/en/About/FAQ/imf-response-to-covid-19. Accessed 27 July 2020.
}

Such collapses will not be overcome with expansionary Keynesian fiscal and monetary policies to support relief and stimulus measures. Most such activities cannot fully resume soon, even in the medium term. Such policies to address collapses in aggregate demand have less relevance in addressing government-mandated restrictions, intended to contain contagion and their many consequences, often unanticipated and unintended.

Many restructured economies will probably emerge from the pandemic, with some doing better than others, probably those able to use the opportunity to develop better new productive and other economic capacities and capabilities. There are and will be greater need and demand for new as well as modified goods and services such as medical supplies, health facilities, care services, distance learning and web entertainment.

Economies trying to adjust to the new post-contagion context—often termed the 'new normal' despite its likely dynamic and transformative character-should optimally use industrial policy, or selective investment and technology promotion to facilitate and expedite desired restructuring. This can be enabled by directing scarce resources from unviable, declining, 'sunset' industries with limited futures to more feasible, emerging, 'sunrise' activities with promising prospects. However, US, Japanese and other political responses are already expediting 'onshoring' previously 'offshored' production for international supply chains at the expense of some fast-growing developing countries. COVID-19 disruptions may also expedite the growing employment-reducing automation, digitization and mechanization of production processes already accelerating before the pandemic (Frey and Osborne 2013).

All workplaces adversely affected by precautionary requirements will need to be safely reconfigured or repurposed accordingly. Structural unemployment problems, due to capabilities' shortages not coinciding with available labour skills, can be better addressed by governmentemployer coordination to appropriately identify, raise and meet skill requirements. Thus, governments need to put in place well-conceived active labour market programmes linking retraining and re-skilling to livelihood support measures to smoothen transition.

Government policies, e.g., using official incentives, can encourage or induce adoption of desirable new practices, such as 'clean investments' for 'green' restructuring, e.g., by using renewable energy and energy saving technologies. China and other East Asian countries have already had some early successes in thus addressing their COVID-19 downturns. Without such inducements, stimuli and support for new investments, desired structural shifts may be much more difficult, painful and costly. Therefore, the ongoing COVID19 crisis should be seen as an opportunity to make much needed, if not long overdue investments in desirable sunrise 
industries, services and enterprises, including personnel retraining and capability enhancement as well as workplace repurposing.

\section{Employment Dimensions}

Almost 2.7 billion workers, around $81 \%$ of the world's workforce, work and earn less due to the COVID-19 recession, with those in lower middle-income developing countries losing most. And almost 1.6 billion in the informal economy are in the hardest hit sectors, significantly impacted by lockdown measures. The longer the lockdowns persist, the greater the economic disruption and adverse impacts as the effects spread via trade and finance linkages to an evergrowing number of countries, firms and households.

In many instances, 'value' or 'supply chains' and production linkages grew with trade and investment 'liberalization' as governments lost tax revenue and control over foreign private enterprises. Such production units were typically poorly integrated into national economies, thus perhaps limiting their likely initial effects. But as the main motivation for relocating labour-intensive segments to developing countries has been to lower labour costs, employment generated by export-oriented production has been quite considerable in some economies. Therefore, the multiplier effects of reduced employment can be quite widespread, threatening to become extended depressions. By reducing overall or aggregate demand, the COVID-19 crisis has significantly reduced commodity prices, demand for manufactures and for many, especially personal services, which has, in turn, cut labour demand and employment.

Most official attempts to save jobs have been limited to the formal sector, usually involving large enterprises, even though the formal sector usually accounts for a minority of the working population, especially in developing countries. While 55\% in Latin America work in the informal economy, the share in sub-Saharan Africa was more than $65 \%$ outside the primary sector. ${ }^{8}$ Approximately 1.3 billion people in the Asia-Pacific region account for $65 \%$ of the world's informally employed. ${ }^{9}$

While those involved in the informal sector typically lack social protection, rights at work and decent working conditions, the large majority of the workforce do not have the ability or infrastructure to work from home. Most such jobs

\footnotetext{
8 https://blogs.iadb.org/trabajo/es/el-baile-de-cifras-de-la-informalid ad-laboral/. https://www.ilo.org/africa/whats-new/WCMS_377286/ lang--en/index.html. Accessed 27 July 2020.

9 https://www.ilo.org/asia/media-centre/news/WCMS_627585/ lang--en/index.htm\#: :text=Key\%20findings\%20in\%20Asia\%2DPac ific \& text $=$ Almost $\% 20$ all $\% 20$ of $\% 20$ agricultural $\% 20$ employment,secto r\%20(54.1\%20per\%20cent). Accessed 27 July 2020.
}

are not easily remotely done, even by those with the digital means.

\section{Development Impacts}

COVID-19 is taking a heavy humanitarian and economic toll on developing countries with large informal sectors and very weak health systems, threatening to undo progress towards Sustainable Development Goals (SDGs). Even before the current pandemic, many developing countries were unlikely to achieve the SDGs, especially its core principle of 'leaving no one behind', including the most marginalized countries and the vulnerable people everywhere.

According to the United Nations 2020 SDGs Report (UN 2020), the pandemic is expected to push back an estimated 71 million people into extreme poverty in 2020 , recording the first rise in global poverty since $1998 .{ }^{10}$ Some 1.6 billion already vulnerable workers in the informal economy, accounting for half the global workforce, are likely to be significantly affected, suffering an estimated $60 \%$ drop in their incomes in the first month of the crisis. It also highlighted the precarious condition of more than one billion slum dwellers worldwide.

The UN Report warns that with about 55\% of the world's population without access to social protection, lost incomes and rising prices mean even those previously secure could find themselves at risk of poverty and hunger. In late March, the United Nations Development Programme (UNDP) warned that income losses could exceed US $\$ 220$ billion in developing countries. ${ }^{11}$

Family, petty and small businesses have always had problems accessing capital, credit and liquidity, even in normal times. Thus, most have struggled to survive the COVID19 induced crises. Petty businesses, like street vendors, are particularly hard hit as they do not have much in terms of financial buffers; hence, they are generally more critically dependent on daily cash flows. A May 2020 survey by the International Trade Centre expected one in four small businesses in developing countries to close permanently due to COVID-19 crises, and two-thirds of micro firms to be strongly affected, compared to $42 \%$ of large companies. ${ }^{12}$

\footnotetext{
${ }^{10}$ UNU-WIDER estimates (Sumner et al. 2020) show that under the most extreme scenario of a $20 \%$ income or consumption contraction, the number of people living in poverty could increase by $420-580$ million, doubling the latest official figures for 2018. In some regions, the adverse impacts could result in poverty levels similar to those three decades ago.

11 https://www.undp.org/content/undp/en/home/news-centre/ news/2020/COVID19_Crisis_in_developing_countries_threatens_ devastate_economies.html. Accessed 27 July 2020.

12 https://www.intracen.org/covid19/Blog/Quantifying-the-effec t-of-COVID-19-on-small-business-around-the-world-the-world/. Accessed 22 August 2020.
} 
Before COVID-19 hit, 113 million more people on the planet were already struggling with severe acute food insecurity due to earlier shocks. ${ }^{13} \mathrm{~A}$ joint report of the Food and Agriculture Organization (FAO) and the World Food Programme (WFP) warns that in 25 countries, hunger will rise to famine levels. According to the report (FAO-WFP 2020), more than 130 million people will suffer 'acute food insecurity' by the end of the year, bringing the world total to 265 million. WFP Director David Beasley warned in April that the world risked 'a famine of biblical proportions', warning 3 months later that 'the world's very poorest families have been forced even closer to the abyss'. ${ }^{14}$

As COVID-19 spreads exponentially, there has also been far more concern about food supplies, with a renewed emphasis on food security, defined in terms of greater food production and self-sufficiency, as before the 1990s, rather than more recent redefinitions of food security. Far greater emphasis should be put on nutrition and food safety, especially excessive antibiotic use and extensive use of toxic agricultural chemicals, than concerns about reliance on food imports.

Many do not have much savings, and the decline in remittances has added to the woes of needy recipients. Thus, many families in poverty are forced to sell off, or otherwise lose income generating resources, and become even less able to invest in the health, education and future of their children, with all their irreparable long-term negative effects. ${ }^{15}$

For many in the subsistence economy, 'if there is a $10 \%$ risk of contracting the virus, it still makes economic sense to continue working than to be at a $90 \%$ risk of their families falling into poverty or not eating' (Porras 2020). Rising food prices and costs of other basic needs are likely to heavily impact the most vulnerable and those with lower incomes, especially when there is no adequate social protection or basic public services such as for health or education.

Widespread closure of schools is not only impacting the education of the young, but also on school feeding programmes, and consequent progress in child nutrition (Porras 2020). Moreover, limited access to health services is making matters worse, not only because of COVID-19, but also because of its impact on other diseases such as malaria, Ebola or measles as already weak health systems are further overstretched.

\footnotetext{
13 http://www.fao.org/news/story/en/item/1187744/icode/. Accessed 20 October 2020.

14 https://news.un.org/en/story/2020/04/1062272; https://www.ungen eva.org/en/news-media/news/2020/07/worlds-poorest-being-pushe d-closer-abyss-famine-warns-wfp-chief. Accessed 27 July 2020.

15 https://www.preventionweb.net/news/view/71236. Accessed 20 October 2020
}

While remittances have been estimated to fall by $20 \%$ in 2020 , according to the World Bank, ${ }^{16}$ FDI flows are projected to decline by $30-40 \% .{ }^{17}$ In excess of US $\$ 100$ billion flowed out from developing countries during March-April 2020 - more than thrice the amount during the global financial crisis (GFC) ${ }^{18}$ Sudden large capital outflows have led to depreciation of major emerging markets' currencies by $15 \%$, raising the cost of imports. ${ }^{19}$

As a significant share of developing countries' public debt is held in US dollars, the depreciation would make debt servicing even more difficult. According to the United Nations Conference on Trade, Investment and Development (UNCTAD), developing countries' debt burden may soar to between US\$2.6 trillion and US\$3.4 trillion over the next 2 years. ${ }^{20}$

The declines in oil as well as other commodity prices and tourism will further hamper emerging and developing markets' access to foreign exchange to service their debt. The novel coronavirus pandemic is projected to cut emerging markets' oil and gas incomes by between 50 and $85 \%,{ }^{21}$ and reduce tourism by as much as $80 \%$ in $2020,{ }^{22}$ affecting many who rely on commodity exports and tourism as their main sources of income.

However, the full impact of COVID-19 on development cannot be ascertained as the situation continues to unfold. Nevertheless, in addition to deaths and significant morbidities from the COVID-19 pandemic, there will be substantial costs to the economy and humanity. Responding appropriately and adequately to the pandemic would therefore require drastic government actions, supported by the public and the international community. Besides government capacities and capabilities, transparency and inclusiveness will be critical, especially to ensure 'all of government' engagement and 'whole of society' cooperation and support, while ensuring that the recovery does not further widen pre-pandemic inequalities.

\footnotetext{
16 https://www.worldbank.org/en/news/press-release/2020/04/22/ world-bank-predicts-sharpest-decline-of-remittances-in-recent-histo ry.

${ }^{17}$ https://news.un.org/en/story/2020/03/1060412.

18 https://www.imf.org/en/News/Articles/2020/04/07/sp040920SMs2020-Curtain-Raiser.

19 https://www.brookings.edu/blog/future-development/2020/04/13/ what-to-do-about-the-coming-debt-crisis-in-developing-countries/.

${ }^{20}$ https://unctad.org/en/pages/newsdetails.aspx?OriginalVersion $\mathrm{ID}=2339$.

$21 \mathrm{https} / / /$ markets.businessinsider.com/commodities/news/ energy-prices-iea-and-opec-leaders-expect-up-to-85-incom e-drop-2020-3-1029003432.

22 https://www.unwto.org/news/covid-19-international-tourist-numbe rs-could-fall-60-80-in-2020.
} 


\section{Whither the 'New Normal'}

The pandemic has exposed economic vulnerabilities building up for some time, especially since the 'counter-revolution'-against Keynesian and development economics in the 1980s-accelerated transnational corporation-led privatization, liberalization and globalization. As the world became more interdependent via trade, finance and communications, inequality and economic insecurity have waxed and waned unevenly, exacerbated by deregulation, reregulation, financialization and less public social provisioning, undermining public health and social protection.

Economic growth slowdowns, especially in manufacturing, services and trade, started prior to the COVID-19 outbreak. Initially, the pandemic's economic effects were expected to be short-term with strict 'stay-in-shelter' lockdowns imposed to stop contagion, requiring factories and offices to be closed. COVID-19 has caused an economic shock three times worse than the 2008 financial crisis, ${ }^{23}$ and it is not over yet, as the death toll already exceeding one million with cases continuing to mount worldwide.

The IMF has supported government fiscal and monetary initiatives, declaring that it 'stands ready to mobilize its US\$1 trillion lending capacity to help its membership' (IMF 2020b). The World Bank has also promised an additional US\$14 billion to help governments and businesses address the pandemic. ${ }^{24}$

The IMF also approved debt service relief for 25 eligible low-income countries (LICs), estimated at around US\$213.5 million, for 6 months, i.e., from 14 April until mid-October 2020. On 15 April, G20 leaders announced their 'Debt Service Suspension Initiative for Poorest Countries' from May to the end of 2020 for 73 primarily LICs. Now extended for another 6 months, this would cover around US\$20 billion worth of bilateral public debt owed by LICs.

Such steps are welcome, providing some temporary relief, but far short of the long-term public and publicly guaranteed external debt stock of eligible countries, of around US $\$ 457$ billion in 2018. Meanwhile, the G20 initiative is already seen as merely 'kicking the can down the road'. ${ }^{25}$ Unlike the Heavily Indebted Poor Country Initiative and the Multilateral Debt Relief Initiative, the G20 initiative did not cancel the debt, which is to be repaid, in full, during 2022-2024, as

\footnotetext{
23 https://www.weforum.org/agenda/2020/09/an-economist-explainswhat-covid-19-has-done-to-the-global-economy/. Accessed 20 October 2020.

24 Press Release, 17 March. https://www.worldbank.org/en/news/ press-release/2020/03/17/world-bank-group-increases-covid-19-respo nse-to-14-billion-to-help-sustain-economies-protect-jobs. Accessed 7 September 2020.

25 https://www.devex.com/news/g20-imf-deliver-on-debt-relief-butmore-is-needed-experts-say-97021. Accessed 20 October 2020.
}

interest continues to accumulate. The inadequate response from the international community may be overtaken by events.

A March G-7 countries' joint statement promised 'a strongly coordinated international approach', ${ }^{26}$ with no specific actions mentioned or forthcoming thereafter. Instead, countries have pursued their own divergent strategies, even banning exports of medical equipment much needed elsewhere, not least by economies previously discouraged, if not prevented from protecting 'infant industries' to produce them. Meanwhile, the Trump administration continues to prioritize 'America First' while undermining most multilateral institutions and even plurilateral arrangements, including those created by earlier US administrations, such as the G20. Already, G7 and G20 members have been dragged into US-China tensions, as the White House blames China for the pandemic and all manner of other American problems.

\section{Preventing Recessions from Becoming Depressions}

Governments must sustain livelihoods to prevent COVID-19 recessions from becoming protracted depressions. For various reasons, largely due to conditions favouring contagion, the crisis has especially affected urban areas, particularly where populations, residences, workplaces and social interactions are more spatially concentrated (Muggah and Florida 2020). The end of a business also has broader implications with long-term costs. Relations, including trust, among entrepreneurs, workers and customers will be disrupted, and will need to be rebuilt, while fired workers will seek new livelihoods. Conventional economic wisdom presumes no 'transactions costs' for recruiting workers, seeking and keeping clients and customers, obtaining credit, investing capital, building trust and other transactions. Consequently, economic policy thinking is often increasingly divorced from reality and thus rendered irrelevant.

Hence, helping businesses and workers survive the crisis due to precautionary and preventive measures forcing them to be idle, or to go into suspension or 'hibernation', is vital. The precarious livelihoods of many of the vulnerable have been undermined, sometimes irreversibly, and may no longer be viable in the new circumstances. Rather than trying to return to the status quo ante, the challenge is to create conditions for a far more inclusive and sustainable economy.

\footnotetext{
${ }^{26}$ G7 Leaders' Statement. 16 March. https://www.whitehouse.gov/
} briefings-statements/g7-leaders-statement/. Accessed 5 August 2020. 


\section{Relief, Recovery and Stimulus Measures: No 'one size fits all'}

While recessions are always different and uneven in impact, different sectors, industries, services and businesses are being affected quite differently, and rather distinctively from earlier recessions. COVID-19 relief measures have often been influenced by policymakers' perceptions of 'best practices', typically from developed Western countries, as well as the nature and consequences of the recessions and their own fiscal and public health capacities.

Fiscally constrained governments need additional budgetary resources via increased borrowing, incurring more public debt, preferably on preferential terms available to governments which can be facilitated by multilateral financial institutions for foreign exchange needs. Economies are neither monolithic nor homogenous, and no single inflexible policy can possibly be suitable for all. Much has to be learnt quickly from experience, from learning by doing. Verification and correction can take place later, perhaps after lockdowns are over.

Although many policymakers and observers use the terms interchangeably, there is a huge difference between relief and recovery measures, with the latter more likely to involve stimuli. Relief measures try to mitigate the adverse consequences of recessions on populations, while stimulus measures typically purport to contribute to economic recovery.

Of course, relief measures for those losing incomes can help mitigate the effects of the adverse supply and demand shocks involved. But much depends not only on direct, but also on indirect, second or even third order effects, partly captured by Keynes' 'multiplier'. A necessary precondition for the multiplier to accelerate broader economic recovery is the prior existence of underutilized productive capacities and capabilities. Otherwise, increasing demand, enabled by easy liquidity, may simply raise prices when output and efficiency cannot be quickly increased profitably.

Economic recovery is conventionally conceived of as a return to the status quo ante, or as restoring economic expansion trajectory. However, recovery should be seen as an opportunity to 'build back better' through development and transformation. Of course, relief measures may have catalytic effects on the economy, e.g., by augmenting aggregate demand, amplified by multiplier effects. However, it is important to analytically estimate and not guess, let alone exaggerate such effects without specific analysis.

Following the initial shock from the COVID-19 pandemic, governments and central banks responded with massive injections of liquidity. However, with deficit financing actively discouraged by influential neoliberal financial pundits, bold fiscal measures were largely eschewed by much of the world. With recent financial crises and recessions in mind, many measures were hastily conceived. But many of the predominantly monetary measures have failed to sustain consumption and save jobs and livelihoods, let alone generate new job-creating investments.

Much of the money has been deployed via measures which have not reached most vulnerable sectors or households, and hence could not offer much relief to liquidityconstrained small and micro-enterprises, and lower-income households. A survey by UNIDO claimed that the shares of firms benefitting from government support measures or stimulus packages ranged from around 10\% (in Afghanistan and Vietnam) to 50\% (in Malaysia and Mongolia). ${ }^{27}$ Overall, larger firms were more likely to receive support than smaller ones, which tend to be more vulnerable and face greater difficulties accessing finance, even in 'normal' times. In Bangladesh, such biases also favoured export-oriented manufacturing. ${ }^{28}$ Significant amounts may also have 'leaked out' of developing countries in the process (Rowden 2020).

The long shadow of financial follies of the last decade, which retarded 'recovery' from the 2008-2009 Great Recession, seems likely to continue to hobble recovery and progress, despite 'unconventional monetary measures', especially in the north Atlantic economies. The unprecedented nature of the crisis has generated greater uncertainty, discouraging household consumer spending and business investments as apprehension encourages holding cash savings for future exigencies. Undoubtedly, much household and business liquidity, including additional resources made available by governments in rich countries, was not spent, due to uncertainty about the future and reduced spending options, resulting in a situation akin to a 'Keynesian liquidity trap'.

At the same time, while available liquidity has not been fully utilized, many interested and even needy borrowers were deemed uncreditworthy. Even those with access to financial resources often bide their time before making opportunistic predatory acquisitions. Likely catalytic benefits were further retarded by such liquidity measures' limited multiplier effects. Thus, early emphasis on liquidity provision appears to have unwittingly enabled debt, inflation and financial speculation, keeping share and other asset markets buoyant, while doing little to encourage the consumption and investment needed for recovery.

With firms preoccupied with economic uncertainty and continued economic vulnerabilities, investment and recovery have been delayed. In this situation, government spending,

\footnotetext{
27 https://www.unido.org/stories/coronavirus-economic-impact-10july-2020. Accessed 20 August 2020.

28 The Bangladesh government's US $\$ 8$ billion stimulus package, worth about $2.5 \%$ of the country's gross domestic product (GDP), primarily focuses on industries, particularly export-oriented ones. It leaves out the most vulnerable sections of society and many sectors desperately needing support (Riaz 2020)
} 
investments and guarantees are needed to break vicious circles. Many countries help businesses by supporting wage and other costs on condition they retain employees. Meanwhile, income-contingent loans have been used to encourage consumer spending and desirable business investments, e.g., for renewable energy. For instance, Chinese municipal authorities have issued expenditure vouchers or coupons with expiry dates to buy certain goods and services to enhance consumption and thus aggregate demand in the short term.

\section{Appropriate Government Interventions Potentially Decisive}

No matter what governments do, there will be unavoidable real output losses as demand too has collapsed. But appropriate, timely and effective interventions can alleviate economic hardship and minimize lasting damage to the economy.

Crucially, governments can prevent brief recessions from becoming longer lasting stagnations or depressions. Without appropriate government measures, output losses due to COVID-19 disruptions will cause large business losses and mass layoffs. Businesses, especially smaller ones with fewer reserves, need to keep their workers and not liquidate their businesses if potentially viable in the new circumstances.

Many businesses may not have enough cash flow to survive major demand shortfalls. Such businesses may go bankrupt, severely affecting workers' families, many related businesses and those involved. Governments need to help employers pay involuntarily idle workers, and help cover unavoidable overhead and maintenance costs during 'stay in shelter' lockdowns. Postponing tax payments may help, but again are not well targeted, since general tax relief benefits indiscriminately, rather than the most affected and needy businesses and workers.

Even when no longer operating, rent, lease, infrastructure, utility and other such payments, health protection for employees and other costs vital for business maintenance need to be made or absorbed. A few, mainly developed countries have acted to stop mass layoffs and business destruction, but much more needs to be done to address the specific problems faced by small family businesses. Well-designed targeted measures are needed to change contracts and other obligations to enable businesses to better deal with the enforced suspension of their business operations due to the COVID-19 disruptions.

\section{Appropriate Relief Programmes}

Unfortunately, existing programmes and proposals to address COVID-19's economic effects are not adequate to avoid a protracted recession or depression. Trying to maintain aggregate demand does not make much sense during actual lockdowns as people can no longer buy many goods and services. Income maintenance policies need to help fired workers and others who have lost their livelihoods. Low-paid and casual workers are more likely to be displaced by lockdowns, being less likely to work from home, and less likely to have much savings to replace temporary earnings losses.

Social protection measures are generally much more institutionalized in developed welfare states. Many measures have been introduced in developing countries, often as temporary, one-off 'social safety nets' responding to particular crises. Such relief measures are often badly targeted, not helping many in need, with too little for those in greatest need, while evidence suggests that relief measures for the poor 'leak' to production by enhancing modest investments. Although policymakers insist on typically costly and inaccurate targeting in anti-poverty programmes, most do not insist on the same when it comes to businesses.

Many governments have responded by providing liquidity-e.g., by offering low-interest or interest-free loans- to help businesses and workers survive the crisis. But such measures have clearly been inadequate to allow them to smoothen costs over a longer time period. Temporary and partial compensation for income losses will enable businesses to resume activity more easily after 'enforced suspensions' due to containment measures, instead of being weighed down by heavy debt burdens. Many businesses need help to survive, and aid should be provided to minimize worker retrenchments.

In the circumstances created by this pandemic, extraordinary, novel social protection measures are needed to assist businesses and workers. One novel proposal has been for the government to serve as a 'payer-of-last-resort' to help 'suspended' or 'hibernating' businesses continue paying their workers, instead of firing them, and to settle unavoidable bills to avoid bankruptcy (Saez and Zucman 2020). It is urgent to ensure cash flows to idle workers and businesses. 'Payer-of-last-resort' programmes can be affordable if they complement effective contagion containment measures, enabling early resumption and recovery of economic activity. Thus, while unavoidably high, costs remain manageable. Direct payments to individuals undoubtedly help alleviate temporary economic hardship. Unemployment benefits can be progressive, with a higher fraction of earnings for the lowest paid.

\section{Neoliberal Economics Blocks Deficit Financing}

Generally constrained by market-driven fears of deficit financing, fiscal measures have largely been limited, if not eschewed, by many governments for fear of being accused of 'irresponsibly' engaging in 'deficit financing' and increasing 'public debt'. The range of deficit financing options has 
changed little since some were first legitimized by Roosevelt and Keynes in the 1930s and used extensively to finance wartime government spending and post-war reconstruction. Meanwhile, the Western turn to 'unconventional monetary measures' in the last decade has influenced many more developing countries to pursue credit and other monetary policies despite differences in their circumstances.

Instead of consistently counter-cyclical fiscal policies over the course of business cycles, neoliberal economists dogmatically insist on minimal annual budget shortfalls in the short-term, regardless of the recession's nature and duration. Their preferred 'supply-side' policy options include more tax cuts, as well as deregulation of businesses and industrial relations (Makin 2020), ${ }^{29}$ even though such measures already contributed to pre-COVID vulnerabilities and economic insecurity, thus exacerbating current predicaments. While the IMF and World Bank are currently supportive of extra-ordinary reflationary fiscal measures, both are still issuing warnings about rising debt, especially for developing countries with 'limited fiscal space' (IMF 2020c). ${ }^{30}$

Recalling alarmist cries for 'fiscal consolidation' once major financial interests had been bailed out after the 2008-2009 GFC, there has been a renewed chorus of warnings about 'impending debt crises' in developing countries. Thus, a wide range of protagonists professing concern for developing countries' plight-from the President of the World Bank, some UN quarters and civil society activists, such as the Jubilee Debt Coalition ${ }^{31}$ — understandably appealed for debt relief, cancellation and restructuring, even buybacks before the COVID-19 crisis. However, such 'well intentioned' appeals divert attention from the urgent need for fiscal space to help overcome the worst of the crisis. Seemingly oblivious to the changed circumstances, some even suggest using donor, MDB or IMF finance for bond buybacks (Stiglitz and Rashid Stiglitz and Rashid 2020a, b)

\footnotetext{
29 The Australian government announced such a policy package in its latest budget, welcomed by business interests; https://www.pwc. com.au/press-room/2020/covid-19-federal-budget-will-help-austr alian-economy-dig-itself-out-of-recession.html. Accessed 20 October 2020.

30 The IMF also issued a working paper (no. 20/137) on 24 July 2020 by Lian et al. (2020), which warns that high public debts can lead to adverse future 'interest rate-growth differentials' dynamics.

$31 \mathrm{https}$ ///www.project-syndicate.org/commentary/suspend-emerg ing-and-developing-economies-debt-payments-by-carmen-reinhartand-kenneth-rogoff-2020-04; https://www.jubileeusa.org/pr_world _bank_says_bold_debt_relief_plans_needed_to_confront_covid_crisi s; https://www.piie.com/blogs/realtime-economic-issues-watch/debtstandstills-can-help-vulnerable-governments-manage-covid; https:// www.eurodad.org/jubilee2020; https://www.bloomberg.com/news/ articles/2020-04-22/un-to-call-for-new-global-body-to-help-withdebt-relief. Accessed 20 August 2020.
}

instead of addressing new priorities dictated by the COVID19 contingency.

Developing country debt had been rising well before the pandemic, especially after the 2008-2009 GFC. Such borrowing was enabled by 'unconventional' monetary policies in major OECD economies, with 'excess' liquidity flowing to developing economies in search of higher returns. More importantly, the composition of debt has become riskier with the shift from bank to financial market borrowings. The nominal privatization and corporatization of stateowned enterprises in recent decades has also contributed to rising private sector debt involving government-guaranteed 'contingent liabilities'. Such debt was often not subject to parliamentary oversight, and hence more liable to abuse. In many developing countries, governments will be expected to take over private sector debt in the wake of widespread COVID-19 bankruptcies, even when not contractually government guaranteed.

Crises do offer opportunities to restructure, including debt. For example, Ecuador's bond buybacks as part of its strategic external debt restructuring was initiated during the 2008-2009 GFC to secure relief from illegitimate 'odious debt' (Feibelman 2017). Not compelled by circumstances to easily compromise, Ecuador repurchased over $90 \%$ of its sovereign debt through financial intermediaries, at 35 cents on the dollar, as its bond prices fell.

Argentina seems to have followed a similar strategy. Citing the COVID-19 crisis, on April 16, Argentina demanded that creditors accept new securities to replace US $\$ 65$ billion worth of bonds, almost $40 \%$ of its foreign currency debt. In early August, Argentina concluded a deal to replace their defaulted bonds with new bonds, for under 55 cents for every dollar of the original value. Observers suggest that 'It's an outcome that the government and bondholders can live with', and will prevail over any hold-out bondholders. Besides huge fiscal savings, the deal avoids reputational damage due to a 'full, open-ended default'. ${ }^{32}$ Having settled with private creditors, Argentina prepared to negotiate with the IMF to delay US $\$ 44$ billion in debt payments due in 2021-2023 to avoid having to impose harsh austerity measures.

Both the Ecuador and Argentina debt buybacks were strategic national initiatives during extraordinary international circumstances, i.e., the GFC in the case of Ecuador and the COVID-19 pandemic recession for Argentina. Neither case involved donors or MDBs. These successful instances of national debt restructuring suggest considerable scope for national initiatives with the requisite political commitment.

Moreover, earlier debt buybacks (e.g., the 'Brady plan' three decades ago) mainly benefitted creditor banks

\footnotetext{
32 https://www.ft.com/content/ecb81529-7853-4403-95a9-577ee 1ebc4b8. Accessed 22 August 2020.
} 
(Berthélemy and Lensink 1992), while debtor countries were forced to implement onerous Fund-Bank aid conditionalities. Similarly, the more recent 2012 Greek bond buybacks, backed by the EC, the ECB and the IMF 'troika', effectively bailed out the mostly French and German banks while Greece was forced to implement severe austerity measures (Markose 2015). Despite celebrating it as a success, it neither restored Greece's growth nor reduced its debt burden (Toussaint 2018).

Hence, prioritizing debt buybacks using donor money is a problematic distraction when the 'need of the hour' is for urgent fiscal support for adequate and appropriate relief and recovery measures. Debt buybacks and restructuring typically require protracted negotiations which may not even achieve much considering the large number of private creditors and powerful lobbies involved, especially in trying to negotiate bond buybacks. Instead of funding bond buybacks, MDBs should return to their traditional 'intermediation' role of mobilizing funds for lending to developing countries at minimal cost to prevent COVID-19 recessions becoming protracted depressions further setting back progress in terms of welfare and development. The IMF's emergency lending capacity should be enhanced with SDRs to prevent recessions from becoming protracted depressions.

\section{Concluding Remarks}

The COVID-19 contagion has been disruptive and costly. Governments have adopted various monetary and fiscal measures to try to revive and sustain economic activity. These include cash transfers to households, extending unemployment insurance or social security benefits, temporarily deferring tax payment deadlines, and increasing credit guarantees and loans to businesses. Such measures, hurriedly taken, have been both inadequate and poorly implemented while doing little for the most vulnerable and needy, thus deepening pre-COVID-19 inequalities. Early 'stimulus packages' assumed that 'pandemic shocks' would be shortlived and easily reversible. Even now, they largely fail to address unsustainability, inequality, instability and other vulnerabilities.

Unconventional monetary policies have not addressed liquidity problems due to sudden and involuntary reduced business turnover without correspondingly reduced liabilities. Increased liquidity provision has largely benefited large firms deemed better 'credit risks', sometimes fuelling inflation while doing little for the most vulnerable and needy small and medium enterprises. Even before COVID-19, such policies were already creating stock market bubbles and facilitating shareholder value extraction, instead of financing investments in the real economy, thus slowing growth and deepening inequality. Central banks have not been able to repair enterprises' balance sheets or draw back excess liquidity, for fear of triggering financial sector collapse. Thus, they have unintentionally increased financial fragility by injecting more liquidity, inadvertently increasing speculation.

Without better planned coordination, relief measures for households and businesses were often wrongly portrayed as fiscal stimulus packages while output remained constrained by reduced aggregate demand, both nationally and globally. Despite cuts in government expenditure, especially for public health and social protection, there has been little political will to increase taxation, especially progressively, before the COVID-19 crisis. Mounting government debt, already historically high and still rising prior to the pandemic, has not helped. Instead, earlier tax cuts have caused increased public borrowing and debt, while failure to improve fiscal capacities and space after the 2008-2009 GFC has meant eschewing productivity-enhancing public investments, strengthening universal health coverage and social protection.

Design and implementation of policies matter, crucially affecting likely effects. As countries prepare for recovery, governments must ask what 'recovery' can and should mean. To address problems, recent and accumulated, it should not mean a return to 'business as usual'. Workplaces and public spaces-where people meet, socialize, shop, etc.-have to be redesigned and repurposed to meet precautionary public health requirements, such as physical distancing. The unsustainable, financialized and grossly unequal pre-COVID-19 economy needs to and can be fundamentally transformed. COVID-19 policy responses have rarely addressed deeper prior malaises, such as stagnant or falling productivity growth and declining labour remuneration. 'Industrial policy' measures, also addressing global warming, resource exhaustion and other sustainability challenges, need to be pragmatically considered and pursued.

The stagnation of the last decade was due to the failure to adequately reform after the GFC. COVID-19 recessions are undoubtedly different from recent financial crises, and need bolder and innovative fiscal, financial and industrial policy measures to sustain economic relief, recovery and restructuring to address previous maladies and the post-lockdown malaise. In designing relief and recovery measures, governments must consider: '(1) How to save lives as part of the health response; (2) How to make sure we can exit from our current predicament permanently, sooner rather than later; and (3) How to protect the development gains made in recent decades' (Dercon 2020). Therefore, governments must act urgently and proactively in public health, as appropriate, and in preparing for better recoveries for economies, firms and families. 'Resources spent on these now will not be wasted in any scenario' (Dercon 2020: 1).

However, neoliberal economists have been misleadingly warning against needed deficit financing for relief and recovery. The implications of borrowing domestically or 
externally are important. For example, Japan's total government debt is now much more than double its annual national income, but this is not considered especially problematic as most of its debt is domestically held by Japanese. The widespread use of unconventional monetary measures since the 2008-2009 Great Recession following the GFC has also forced economists to reconsider earlier Friedmanite monetarist articles of faith, boosting 'modern monetary theory'. Central banks can help meet governments' borrowing requirements especially when there is idle capacity in the economy.

Developing countries with limited foreign exchange reserves should restrict non-essential imports, put in place prudential capital account measures and keep exchange rates undervalued to boost exports. But an overvalued exchange rate is favoured by elites wanting strong currencies, which they portray as cause for national pride. A strong exchange rate worsens balance of payments' difficulties in the longer term, while favouring consumers over producers and importers over exporters, besides encouraging consumption at the expense of savings.

Overvalued exchange rates' potential for curbing inflation is problematic as balance of payments' deficits cannot be sustained indefinitely. Foreign exchange-based currency board and other stabilization arrangements in transition and developing economies are similarly problematic. Economies maintaining overvalued exchange rates have often subsequently experienced severe currency crises. Nationalist development ideologies and weak elite opposition enabled many East Asian economies to use undervalued exchange rates to discourage imports and boost exports, with effective protection for import-substituting industries conditional on successful export promotion.

In recent years, the ascendance of jingoism, or 'ethnonationalism' based on 'ethno-populism', has attacked and at least partly reversed some dimensions of the variegated phenomena termed globalization and neo-liberal economics. These have significantly undermined economies which had opened up to international trade and investment in some ways, including, but not limited to, participating in global supply or value chains. US President Trump's jingoism has been central to the ongoing assault on multilateralism and even plurilateralism, including arrangements made by previous US administrations. Other jingoist regimes have more ambivalent attitudes to his economic policy reversals which have significantly reduced trade and investment prospects for countries producing for export.

Remarkably, there has been even fewer gestures of international cooperation and solidarity in response to the COVID-19 crisis, in contrast to the rhetorical responses to the 2008-2009 GFC and ensuing Great Recession. Despite all the rhetoric at the time, protectionist trade measures were adopted by most developed economies. Hence, there has been relatively little expansion of international trade in the decade since.

Decades of neoliberalism have led to the ethno-populist reactions of recent times which have, in turn, strengthened the new irrationalities, anti-science and anti-ecological sentiments exacerbating often irreversible planetary damage, including global warming. Meanwhile, the ascendance of finance, new modes of rent-gouging and short-termist considerations have redefined business priorities with ecologically destructive and socially disequalizing and divisive consequences.

Yet, the crisis also presents the world with an opportunity to move forward although the path remains obscure, while the needed leadership is missing. There is much to quickly learn and do to progress, including abandoning the very modes of thinking which have led to the current quagmire. Exorcising the ghosts of economic and other ideologies from the past will be imperative for sorely needed progress.

\section{References}

Berthélemy, Jean-Claude and Robert Lensink. 1992. An Assessment of the Brady Plan Agreements. OECD Development Centre Working Paper No. 67 (May), https://www.oecd-ilibrary.org/docse rver/615827578321.pdf?expires $=1603632725 \& \mathrm{id}=\mathrm{id} \&$ accna me $=$ guest $\&$ checksum $=91$ FE3B4B44C4D0FB3016781B48B6F2 27. Accessed 26 October 2020.

Dercon, Stefan. 2020. No-Regret Policies for the COVID-19 Crisis in Developing Countries. Center for Global Development Note, April, https://www.cgdev.org/sites/default/files/no-regret-policiesCOVID-19-crisis-developing-countries.pdf. Accessed 20 October 2020.

Feibelman, Adam. 2017. Ecuador's 2008-09 Debt Restructuring: A Special Case? In Juan Pablo Bohoslavsky and Kunibert Raffer (eds). Sovereign Debt Crises: What Have We Learned? Cambridge University Press, Cambridge, UK; also available as Tulane Public Law Research Paper No. 17-5.

Gurara, Daniel, Stefania Fabrizio, and Johannes Wiegand. 2020. COVID-19: Without Help, Low-Income Developing Countries Risk a Lost Decade. IMF Blog, 27 August. https://blogs.imf. org/2020/08/27/covid-19-without-help-low-income-developing -countries-risk-a-lost-decade/ Accessed 17 October 2020.

FAO-WFP. 2020. FAO-WFP early warning analysis of acute food insecurity hotspots. July. https://docs.wfp.org/api/documents/WFP0000117706/download/?_ga $=2.17740153 .159474418 .15956$ 03901-194005410.1595603901. Accessed 27 July 2020.

Frey, Carl, and Michael Osborne. 2013. The Future of Employment: How Susceptible are Jobs to Computerisation? Oxford Martin School Working Paper, 17 September. https://www.oxfordmart in.ox.ac.uk/downloads/academic/future-of-employment.pdf. Accessed 4 September 2020.

Gallagher, Kevin, José Antonio Ocampo and Ulrich Volz. 2020. Special Drawing Rights: International Monetary Support for Developing Countries in Times of the COVID-19 Crisis. The Economists' Voice, 17 August, https://www.degruyter.com/view/ journals/ev/ahead-of-print/article-10.1515-ev-2020-0012/article10.1515-ev-2020-0012.xml?language $=e n$. Accessed 20 October 2020 . 
Herman, Barry. 2020. The Looming Developing Country Debt Crisis and the Fear of Imposed Austerity. The New School IndiaChina Institute Blog, 15 October. https://www.indiachinainsti tute.org/2020/10/15/the-looming-developing-country-debt-crisi s-and-the-fear-of-imposed-austerity/. Accessed 20 October 2020.

IMF. 2020a. World Economic Outlook: The Great Lockdown. April, International Monetary Fund, Washington, DC.

IMF. 2020b. Policy Steps to Address the Corona Crisis. https://www. elibrary.imf.org/doc/IMF007/28916-9781513536927/28916 -9781513536927/Other_formats/Source_PDF/28916-9781513537 122.pdf?redirect $=$ true. Accessed 7 September 2020.

IMF. 2020c. Fiscal Monitor: Policies for the Recovery. October. https ://www.imf.org/en/Publications/FM/Issues/2020/09/30/october2020-fiscal-monitor. Accessed 20 October 2020.

Lian, Weicheng, Andrea F. Presbitero, and Ursula Wiriadinata. 2020. Public Debt and $r$ - $g$ at Risk. IMF Working Paper no. 20/137, 24 July. https://www.imf.org/en/Publications/WP/Issues/2020/07/24/ Public-Debt-and-r-g-at-Risk-49586. Accessed 20 October 2020.

Makin, Tony. 2020. Coronavirus: It's Keynes's fault - again we go into debt to 'stimulate' the economy. The Australian, 17 June. https://www.theaustralian.com.au/commentary/coronavirus-itskeyness-fault-again-we-go-into-debt-to-stimulate-the-economy/ news-story/91e68081f0bdf36d154f377542ef7b40. Accessed 20 October 2020.

Markose, Sheri. 2015. A tragedy in three parts: how the Greek debt crisis unfolded. The Conversation, 16 July. https://theconversation .com/a-tragedy-in-three-parts-how-the-greek-debt-crisis-unfol ded-44680. Accessed 26 October 2020.

Muggah, Robert, and Richard Florida. 2020. COVID-19 will hit the developing world's cities hardest. Here's why. World Economic Forum, 27 May. https://www.weforum.org/agenda/2020/05/covid -19-will-hit-the-developing-worlds-cities-hardest-heres-why/. Accessed 27 July 2020.

Porras, Borja Santos. 2020. Controlling COVID-19 will carry devastating economic cost for developing countries. Conversation, 2 June. https://theconversation.com/controlling-covid-19-will-carry-devas tating-economic-cost-for-developing-countries-139492. Accessed 27 July 2020.

Riaz, Ali. 2020. Bangladesh's COVID-19 stimulus: Leaving the most vulnerable behind. Atlantic Council, 8 April. https://www.atlan ticcouncil.org/blogs/new-atlanticist/bangladeshs-covid-19-stimu lus-leaving-the-most-vulnerable-behind/. Accessed 20 August 2020 .
Rowden, Rick. 2020. Covid-19 and Illicit Financial Flows: What's to Come. Global Financial Integrity, 6 May. https://gfintegrity.org/ covid-19-and-illicit-financial-flows-whats-to-come/. Accessed 20 August 2020.

Saez, Emmanuel, and Gabriel Zucman. 2020. Keeping Business Alive: The Government Will Pay. Social Europe, 18 March. https://www. socialeurope.eu/keeping-business-alive-the-government-will-pay. Accessed 20 August 2020.

Stiglitz, Joseph, and Hamid Rashid. 2020a. Averting Catastrophic Debt Crises in Developing Countries: Extraordinary Challenges Call for Extraordinary Measures. Centre for Economic Policy Research Policy Insight 104, July, London. https://cepr.org/sites /default/files/policy_insights/PolicyInsight104.pdf. Accessed 20 August 2020.

Stiglitz, Joseph, and Hamid Rashid. 2020b. Which Economic Stimulus Works? Project Syndicate, 8 June. https://www.project-syndi cate.org/commentary/stimulus-policies-must-benefit-real-econo my-not-financial-speculation-by-joseph-e-stiglitz-and-hamid-rashi d-2020-06. Accessed 20 August 2020.

Sumner, Andy, Chris Hoy, and Eduardo Ortiz-Juarez. 2020. Estimates of the Impact of COVID-19 on Global Poverty. WIDER Working Paper 2020/43. https://www.wider.unu.edu/sites/default/files /Publications/Working-paper/PDF/wp2020-43.pdf. Accessed 7 September 2020.

Toussaint, Eric. 2018. The Troika's Policy in Greece: Rob the Greek people and give the money to private banks, the ECB, the IMF and the dominant States of the Eurozone. Committee for the Abolition of Illegitimate Debt. 28 August. https://www.cadtm.org/The-Troik a-s-Policy-in-Greece-Rob-the-Greek-people-and-give-the-money -to. Accessed 26 October 2020.

United Nations (UN). 2020. The Sustainable Development Goals Report 2020. United Nations, New York. https://unstats.un.org/ sdgs/report/2020/The-Sustainable-Development-Goals-Repor t-2020.pdf.

Publisher's Note Springer Nature remains neutral with regard to jurisdictional claims in published maps and institutional affiliations. 